\title{
PROFIL PERSALINAN KEHAMILAN KEMBAR \\ DI BLU RSUP PROF. DR. R. D. KANDOU MANADO PERIODE 01 JANUARI 2010 - 31 DESEMBER 2011
}

\author{
${ }^{1}$ Angelina Tuange \\ ${ }^{2}$ Hermie M. M. Tendean \\ ${ }^{2}$ Freddy W. Wagey
}

\author{
${ }^{1}$ Kandidat Skripsi Fakultas Kedokteran Unsrat Manado \\ ${ }^{2}$ Bagian Obstetri-Ginekologi Fakultas Kedokteran Unsrat Manado \\ Email: angel_tuange@yahoo.com
}

\begin{abstract}
Background: Twin pregnancies is the pregnancies with two fetues or more. Nation, heredity, age and parity of mother are all factors affecting twin pregnancies. The main factors that increase the the possibilities of multiple pregnancy is the treatment of infertility. This study uses a retrospective descriptive through medical records at BLU RSUP Prof. Dr. R. D. Kandou in period January 01, 2010 - December 31, 2011. Conclusion: It is already found 97 cases of twin pregnancy deliveries from 7265 total deliveries. There are 85 cases with a history af multiple pregnancies in the family. Best mode of delivery by Sectio Caesarea as many as 47 cases. Perinatal mortality still occur due to complications and complications that occur during labor. Complications can occur at any time, so it is important with the availability of doctor who are experienced in handling complications of twin pregnancies, to produce the maximum infant output and minimize morbidity and mortality.
\end{abstract}

Keyword: Maternity of twin pregnancies, number of incidence

\begin{abstract}
Abstrak: Latar belakang: Kehamilan kembar adalah kehamilan dengan dua janin atau lebih. Bangsa, hereditas, umur, dan paritas ibu merupakan faktor-faktor yang mempengaruhi kehamilan kembar. Faktor utama yang meningkatkan kemungkinan terjadinya kehamilan kembar adalah terapi infertilitas. Penelitian ini menggunakan metode retrospektif deskriptif melalui rekam medik di BLU RSUP Prof. Dr. R. D. Kandou periode 01 Januari $2010-31$ Desember 2011. Simpulan: Ditemukan 97 kasus persalinan kehamilan kembar dari 7265 total persalinan. Paling banyak ditemukan pada umur $21-25$ tahun. Terdapat 85 kasus yang memiliki riwayat kehamilan kembar dalam keluarga. Cara persalinan yang paling banyak dengan cara Seksio Sesarea sebanyak 47 kasus. Angka kematian perinatal masih saja terjadi disebabkan oleh komplikasi dan penyulit yang terjadi saat persalinan. Komplikasi dapat terjadi kapan saja, sehingga sangat penting akan tersedianya dokter yang berpengalaman dalam penanganan komplikasi dari kehamilan kembar untuk menghasilkan luaran bayi yang maksimal dan meminimalkan morbiditas dan mortalitas.
\end{abstract}

Kata kunci: Persalinan kehamilan kembar, angka kejadian

Kehamilan kembar terdiri atas dua janin atau lebih. Kebanyakan adalah kehamilan kembar dua (hampir 98\%). Ibu dan janin pada kasus kehamilan kembar lebih berisiko dibandingkan pada kasus kehamilan tunggal. Kehamilan dan persalinan memba- wa risiko pada janin. Bahaya bagi ibu tidak begitu besar, tetapi wanita dengan kehamilan kembar memerlukan pengawasan dan perhatian khusus bila diinginkan hasil yang memuaskan bagi ibu dan janin. ${ }^{1}$

Dibandingkan dengan kehamilan tung- 
gal, kehamilan kembar lebih mungkin terkait dengan banyak komplikasi kehamilan. Komplikasi obstetrik yang sering didapatkan pada kehamilan kembar meliputi polihidramnion, hipertensi yang diinduksi oleh kehamilan, ketuban pecah dini, presentasi janin abnormal, partus prematurus, anemia, BBLR dan mortalitas pada bayi. ${ }^{1}$

Kehamilan multipel lebih mungkin terkait dengan banyak komplikasi kehamilan dibandingkan dengan kehamilan tunggal. Karena itu, ibu hamil memerlukan perawatan antenatal tambahan. Ibu harus datang untuk memeriksakan kehamilannya setiap dua minggu dari saat ditegakkan diagnosis. Kebutuhan akan kalori, protein, dan asam lemak esensial jauh lebih meningkat pada ibu dengan kehamilan kembar. Konsumsi energi harus ditingkatkan $300 \mathrm{kkal} / \mathrm{hari}$. Dianjurkan suplementasi besi 60 sampai $100 \mathrm{mg}$ per hari, juga diberikan asam folat $1 \mathrm{mg}$ per hari. ${ }^{1}$

Pada proses persalinan kembar, banyak penyulit persalinan dijumpai, diantaranya yaitu: persalinan preterm, inertia uteri, malpresentasi, prolaps tali pusat, dan perdarahan post partum dini. Karena itu, dalam menangani persalinan dengan janin lebih dari satu diperlukan penanganan dan persiapan khusus. ${ }^{1}$

Kehamilan kembar adalah kehamilan yang terdiri dari dua janin atau lebih. Klasifikasi kehamilan kembar dibuat berdasarkan jumlah janin, jumlah ovum yang dibuahi, jumlah plasenta, dan jumlah organ amnion. $^{2}$

Kembar monozigotik/uniovular/identik terjadi akibat fertilisasi satu ovum oleh satu spermatozoa yang kemudian membelah menjadi dua struktur yang identik; karenanya, pasangan janin tersebut selalu berjenis kelamin sama. Kedua janin dapat berbagi satu plasenta (monokorion) atau masingmasing memiliki satu plasenta (dikorion). ${ }^{2}$

Kembar dizigotik/binovular/non-identik terjadi akibat fertilisasi dua ovum berbeda, yang secara spontan dilepaskan secara bersamaan pada saat ovulasi, oleh dua spermatozoa. $^{2}$

Diagnosis kehamilan kembar didapatkan melalui hasil pemeriksaan yang mem- berikan petunjuk: riwayat keluarga yang positif, uterus dan abdomen kelihatan lebih besar dari yang diharapkan sesuai dengan lamanya amenorrhea, pertumbuhan uters lebih cepat dari normal, penambahan berat badan ibu yang mencolok yang tidak disebabkan oleh edema atau obesitas, banyak bagian kecil teraba. ${ }^{3}$

Diagnosis pasti kehamilan dapat ditentukan dengan: teraba dua kepala atau dua bokong, dua denyut jantung janin yang didengarkan pada waktu bersamaan oleh pemeriksa mempunyai selisih frekuensi paling sedikit 10 denyut per menit, Ultrasonografi menunjukkan adanya dua atau lebih tengokrak janin, pada persalinan lahirnya lebih dari satu bayi merupakan bukti yang positif. $^{3}$

\section{METODE PENELITIAN}

Penelitian ini dilaksanakan dengan cara retospektif deskriptif yang bertujuan untuk mengetahui profil persalinan kehamilan kembar di BLU Prof. Dr. R. D. Kandou Manado. Waktu penelitian 2 tahun yaitu dari 01 Januari 2010 - 31 Desember 2011. Subjek pada penelitian ini ialah semua pasien dengan riwayat persalinan kehamilan kembar di Bagian Obstetri Ginekologi RSUP Prof. Dr. R. D. Kandou Manado periode 01 Januari 2010 sampai 31 Desember 2011.

Variabel penelitian yaitu usia, riwayat kehamilan kembar dalam keluarga, cara persalinan, komplikasi, penyulit, kematian perinatal.

Cara pengumpulan data dengan cara data di kumpulkan secara manual, kemudian diolah secara komputerisasi dan disajikan ke dalam bentuk tabel distributif frekuensi.

Definisi operasional yaitu kehamilan kembar terdiri atas dua janin atau lebih. Kebanyakan adalah kehamilan kembar dua (hampir (98\%). Usia adalah perhitungan ulang tahun ibu yang dihitung sejak tahun lahir sampai ulang tahun terakhir yang tercatat dalam rekam medik. Riwayat kehamilan kembar dalam keluarga adalah riwayat kehamilan kembar yang ada dalam 
keluarga dari pihak ibu atau pihak ayah. Cara persalinan adalah cara persalinan ibu yang mengalami kehamilan kembar yang dikelompokkan dalam; spontan, seksio sesarea, ekstraksi vakum, spontan \& seksio sesarea, spontan \& ekstraksi vakum, ekstraksi vakum \& forcep. Komplikasi adalah komplikasi-komplikasi yang terjadi pada ibu dan bayi seperti partus prematurus, perdarahan, ketuban pecah dini, anemia, apgar skor rendah, BBLR, BBLSR, tali pusat menumbung, gagal napas, ruptur perineum. Penyulit adalah penyulit-penyulit yang terjadi pada ibu dan bayi seperti preeklampsia ringan, preeklampsia berat, inertia uteri, gawat janin. Kematian perinatal adalah angka kematian bayi yang dikelompokkan dalam lahir mati dan kematian neonatal dini.

\section{HASIL PENELITIAN}

Tabel 1. Insiden Persalinan Kehamilan Kembar

\begin{tabular}{cccc}
\hline Tahun & $\begin{array}{c}\text { Jumlah } \\
\text { Persalinan }\end{array}$ & $\begin{array}{c}\text { Kehamilan } \\
\text { Kembar }\end{array}$ & $\%$ \\
\hline 2010 & 2612 & 52 & 1,99 \\
2011 & 4653 & 45 & 0,96 \\
\hline
\end{tabular}

Jumlah persalinan kehamilan kembar yang terbanyak pada tahun 2010 yakni sebanyak 52 kasus $(1,99 \%)$ dari 2612 persalinan. Dan pada tahun 2011 sebanyak 45 kasus $(0,96 \%)$ dari 4653 persalinan.

Tabel 2. Sebaran kasus menurut kelompok usia.

\begin{tabular}{ccccc}
\hline \multirow{2}{*}{ Usia } & \multicolumn{4}{c}{ Tahun } \\
\cline { 2 - 5 } & $\mathbf{2 0 1 0}$ & $\mathbf{\%}$ & $\mathbf{2 0 1 1}$ & $\mathbf{\%}$ \\
\hline$\leq 20$ thn & 5 & 9,62 & 3 & 6,67 \\
$21-25$ thn & 14 & 26,92 & 12 & 26,67 \\
$26-30$ thn & 10 & 19,23 & 11 & 24,44 \\
$31-35$ thn & 13 & 25 & 10 & 22,22 \\
$36-40$ thn & 8 & 15,39 & 9 & 20 \\
$41-45$ thn & 1 & 1,92 & 0 & 0 \\
$\geq 46$ thn & 1 & 1,92 & 0 & 0 \\
Total & $\mathbf{5 2}$ & $\mathbf{1 0 0}$ & $\mathbf{4 5}$ & $\mathbf{1 0 0}$ \\
\hline
\end{tabular}

Kehamilan kembar lebih banyak ditemukan pada kelompok usia 21 - 25 tahun yakni $(26,92 \%)$ tahun 2010 dan (26,67\%) tahun 2011, dan jarang pada usia 41 - 45 tahun yaitu $(1,92 \%)$ dan $\geq 46$ tahun yaitu $(1,92 \%)$ pada tahun 2010 .

Tabel 3. Sebaran kasus menurut riwayat kehamilan kembar dalam keluarga

\begin{tabular}{ccccc}
\hline $\begin{array}{c}\text { Riwayat } \\
\text { Kehamilan } \\
\text { kembar } \\
\text { dalam }\end{array}$ & $\mathbf{2 0 1 0}$ & $\mathbf{\%}$ & $\mathbf{2 0 1 1}$ & $\mathbf{\%}$ \\
keluarga & & & & \\
\hline Gemelli (+) & 47 & 90,38 & 38 & 84,44 \\
Gemelli (-) & 5 & 9,62 & $\mathbf{7}$ & 15,56 \\
Total & $\mathbf{5 2}$ & $\mathbf{1 0 0}$ & $\mathbf{4 5}$ & $\mathbf{1 0 0}$ \\
\hline
\end{tabular}

Pada kehamilan kembar paling banyak memiliki riwayat kehamilan kembar dalam keluarga baik dari pihak Ibu maupun dari pihak ayah yakni $(90,38 \%)$ pada tahun 2010 dan $(84,44 \%)$ pada tahun 2011.

Tabel 4. Sebaran kasus menurut cara persalinan.

\begin{tabular}{|c|c|c|c|c|c|}
\hline \multirow{2}{*}{\multicolumn{2}{|c|}{$\begin{array}{c}\text { Cara } \\
\text { Persalinan }\end{array}$}} & \multicolumn{4}{|c|}{ Tahun } \\
\hline & & 2010 & $\%$ & 2011 & $\%$ \\
\hline $\begin{array}{l}\text { Seksio } \\
\text { Sesarea }\end{array}$ & & 22 & 42,31 & 25 & 55,56 \\
\hline Spontan & & 27 & 51,93 & 16 & 35,56 \\
\hline $\begin{array}{l}\text { Spontan } \\
\text { Ekstraksi } \\
\text { Vakum }\end{array}$ & $\&$ & 0 & 0 & 3 & 6,66 \\
\hline $\begin{array}{l}\text { Ekstraksi } \\
\text { Vakum }\end{array}$ & & 1 & 1,92 & 1 & 2,22 \\
\hline $\begin{array}{l}\text { Spontan } \\
\text { Seksio } \\
\text { Sesarea }\end{array}$ & $\&$ & 1 & 1,92 & 0 & 0 \\
\hline $\begin{array}{l}\text { Ekstraksi } \\
\text { Vakum } \\
\text { Forcep }\end{array}$ & $\&$ & 1 & 1,92 & 0 & 0 \\
\hline Total & & 52 & 100 & 45 & 100 \\
\hline
\end{tabular}

Pada tahun 2010 cara persalinan yang banyak dilakukan yaitu dengan cara Spontan $(51,93 \%)$, sedangkan pada tahun 
2011 paling banyak dengan cara Seksio Sesarea $(55,56 \%)$.

Tabel 5. Sebaran kasus menurut komplikasi

\begin{tabular}{lcccc}
\hline & \multicolumn{4}{c}{ Tahun } \\
\cline { 2 - 5 } Komplikasi & $\mathbf{2 0 1 0}$ & $\mathbf{\%}$ & $\mathbf{2 0 1 1}$ & $\mathbf{\%}$ \\
\hline Partus & 14 & 26,93 & 8 & 17,79 \\
Prematurus & & & & \\
Tanpa & 3 & 5,77 & 18 & 40 \\
Komplikasi & & & & \\
Anemia & 9 & 17,30 & 3 & 6,66 \\
KPD & 8 & 15,40 & 3 & 6,66 \\
Gagal Napas & 4 & 7,70 & 3 & 6,66 \\
Apgar Skor & 1 & 1,92 & 4 & 8,89 \\
Rendah & & & & \\
& & & & \\
TTTS & 4 & 7,70 & 1 & 2,22 \\
BBLR & 2 & 3,84 & 2 & 4,45 \\
Perdarahan & 2 & 3,84 & 2 & 4,45 \\
BBLSR & 2 & 3,84 & 1 & 2,22 \\
Ruptur & 2 & 3,84 & 0 & 0 \\
Perineum & & & & \\
Tali Pusat & 1 & 1,92 & 0 & 0 \\
Menumbung & & & & \\
$\quad$ Total & $\mathbf{5 2}$ & $\mathbf{1 0 0}$ & $\mathbf{4 5}$ & $\mathbf{1 0 0}$ \\
\hline
\end{tabular}

Komplikasi yang banyak terjadi yaitu partus prematurus $(26,93 \%)$ pada tahun 2010 dan $(17,79 \%)$ pada tahun 2011.

Tabel 6. Sebaran kasus menurut penyulit

\begin{tabular}{lcccc}
\hline \multirow{2}{*}{ Penyulit } & \multicolumn{4}{c}{ Tahun } \\
\cline { 2 - 5 } & $\mathbf{2 0 1 0}$ & $\mathbf{\%}$ & $\mathbf{2 0 1 1}$ & $\mathbf{\%}$ \\
\hline Tanpa & 27 & 51,92 & 23 & 51,12 \\
Penyulit & 13 & 25 & 16 & 35,55 \\
Preeklampsia & 5 & 9,62 & 4 & 8,89 \\
Inertia Uteri & 5 & 9,62 & 1 & 2,22 \\
Malpresentasi & 2 & 3,84 & 1 & 2,22 \\
Gawat Janin & & & & \\
$\quad$ Total & $\mathbf{5 2}$ & $\mathbf{1 0 0}$ & $\mathbf{4 5}$ & $\mathbf{1 0 0}$ \\
\hline
\end{tabular}

Penyulit yang sering terjadi yaitu preeklampsia $(51,92 \%)$ pada tahun 2010 dan $(51,12 \%)$ pada tahun 2011.
Tabel 7. Sebaran kasus menurut kematian perinatal

\begin{tabular}{cccccc}
\hline \multirow{2}{*}{ Tahun } & \multirow{2}{*}{$\begin{array}{c}\text { Lahir } \\
\text { Hidup }\end{array}$} & \multicolumn{2}{c}{ Kematian } & & \\
\cline { 3 - 4 } & & Perinatal & Total & $\%$ & KND \\
\cline { 3 - 4 } & & & & \\
\hline 2010 & 2419 & 6 & 8 & 14 & 5,78 \\
2011 & 4433 & 7 & 5 & 12 & 2,70 \\
\hline
\end{tabular}

Kematian perinatal pada tahun 2010 sebanyak 14 kasus $(5,78 \%$ oo dan pada tahun 2011 sebanyak 12 kasus $(2,70 \%$ oo).

\section{BAHASAN}

Penelitian ini merupakan tinjauan retrospektif selama periode 01 Januari 2010 sampai 31 Desember 2011 di BLU RSUP Prof. Dr. R D. Kandou Manado.

Pada Tabel 1 ditemukan 52 kasus persalinan kehamilan kembar (1,99\%) dari 2612 persalinan pada tahun 2010 dan 45 kasus persalinan kehamilan kembar $(0,96 \%)$ dari 4653 persalinan pada tahun 2011.

Pada Tabel 2 terlihat bahwa kasus yang terbanyak adalah usia $21-25$ tahun yaitu sebanyak 14 kasus $(26,92 \%)$ tahun 2010 dan 12 kasus $(26,67 \%)$, kemudian usia 31 35 tahun sebanyak 13 kasus (25\%) tahun 2010 dan 10 kasus $(22,22 \%)$ tahun 2011 , usia $\leq 20$ tahun sebanyak 5 kasus $(9,62 \%)$ tahun 2010 dan tiga kasus $(6,67 \%)$ tahun 2011, yang paling jarang pada usia $\geq 46$ tahun sebanyak satu kasus $(1,92)$ pada tahun 2010. Frekuensi kembar meningkat dengan usia maternal dan jumlah kehamilan. Wanita berusia antara 35-40 tahun dengan empat atau lebih anak, kemungkinan memilki anak kembar adalah tiga kali lipat dibanding wanita berusia kurang dari 20 tahun yang belum memiliki anak.

Pada Tabel 3 terdapat 47 kasus (90,38\%) tahun 2010 dan 38 kasus (84,44\%) tahun 2011 yang memiliki riwayat kehamilan kembar dalam keluarga. Dan terdapat lima kasus $(9,62 \%)$ tahun 2010 dan tujuh kasus $(15,56 \%)$ tahun 2011 yang tidak memiliki riwayat kehamilan kembar dalam keluarga. Riwayat kembar 
pada keluarga ibu lebih signifikan dibanding riwayat kembar dari keluarga ayah. Wanita kembar non-identik memberikan kemungkinan bayi kembar satu kelahiran dari 60 kelahiran. Sebaliknya, seorang ayah yang memiliki kembar nonidentik memberikan kemungkinan bayi kembar hanya satu dari 125 kelahiran.

Pada Tabel 4 diperoleh cara persalinan yang sering tahun 2010 dengan cara spontan 27 kasus $(51,93 \%)$ dan yang sering tahun 2011 dengan cara seksio sesarea 25 kasus $(55,56 \%)$. Melahirkan dengan cara seksio sesarea paling sering dibutuhkan, contohnya ketika janin kedua lebih besar daripada janin pertama dan letak lintang atau letak bokong. Seksio sesarea diperlukan karena serviks dapat berkontraksi dan mengecil setelah bayi pertama lahir dan tidak berdilatasi setelah itu atau bisa juga karena memburuknya detak jantung bayi kedua.

Pada Tabel 5 diperoleh komplikasi yang sering terjadi adalah partus prematurus sebanyak 14 kasus $(26,93 \%)$ tahun 2010 dan delapan kasus (17,79\%) tahun 2011. Hamil lebih dari satu janin akan meningkatkan risiko selama kehamilan, baik bagi janin maupun ibu. Partus prematurus merupakan risiko yang selalu mengancam pada kehamilan kembar, dengan rata-rata usia kehamilan 37 minggu.

Pada Tabel 6 diperoleh yang paling banyak adalah tanpa penyulit. Kemudian preeklampsia sebanyak 13 kasus (25\%) tahun 2010 dan 16 kasus $(35,55 \%)$ tahun 2011. Preeklampsia adalah penyakit dengan tanda-tanda hipertensi, edema dan proteinuria yang sering terjadi pada kehamilan kembar.

Pada Tabel 7 diperoleh kematian perinatal pada tahun 2010 sebanyak 14 kasus $(5,78 \%)$ dan pada tahun 2011 sebanyak 12 kasus $(2,70 \%)$.

\section{SIMPULAN}

Angka kejadian persalinan kehamilan kembar di RSUP Prof. Dr. R. D. Kandou Manado periode 01 Januari 2010 - 31 Desember 2011 sebanyak 97 kasus (1,33\%) dari 7265 kasus persalinan. Usia terbanyak pada 21 - 25 tahun, banyak yang memiliki riwayat kehamilan kembar dalam keluarga, cara persalinan terbanyak dengan cara Seksio Sesarea dan spontan. Komplikasi yang sering terjadi yaitu partus prematurus, penyulit yang sering terjadi yaitu preeklampsia, kematian perinatal pada tahun 2010 sebanyak 14 kasus $(5,78 \%$ oo dan pada tahun 2011 sebanyak 12 kasus $(2,70 \%$ oo $)$.

\section{SARAN}

Pemeriksaan dini kehamilan untuk menentukan apakah janin kembar atau tunggal sangat dianjurkan. Selain itu ibu harus dianjurkan untuk memeriksakan kehamilan secara teratur sesuai petunjuk dokter, terlebih apabila ditemukan kecenderungan akan terjadi komplikasi/penyulit yang dapat membahayakan ibu serta bayi. Komplikasi dapat terjadi kapan saja, sehingga sangat penting akan tersedianya dokter yang berpengalaman dalam penanganan komplikasi dari kehamilan kembar untuk menghasilkan luaran bayi yang maksimal dan meminimalkan morbiditas dan mortalitas.

\section{KEPUSTAKAAN}

1. Wiknjosastro H. Kehamilan Kembar. Dalam: Saifuddin A, Rachimhadhi T, Wiknjosastro H, editor. Ilmu Kebidanan. Jakarta: Yayasan Bina Pustaka Sarwono Prawirohardjo, 2009; hal. 386 - 97.

2. Marsh, MS, Rennie, JM, Groves, PA. Kehamilan Kembar. Dalam: Holmes D, Baker P, editor. Ilmu Kebidanan. Jakarta: EGC, 2011; hal. 125 - 35.

3. Oxorn H, William F. Kehamilan Kembar. Dalam: Mohammad H, editor. Patologi \& Fisiologi Persalinan. Yogyakarta: ANDI, 2010; hal. 261-73. 